\title{
低合金鋼のクリープ破断強度と組織*
}

\author{
行 俊 照 夫** 西 田 和 彦**
}

\section{Properties in Creep of Low Alloy Steels in Relation to their Microstructure}

by

\author{
Teruo YukitosHI and Kazuhiko NishidA
}

(Central Research Laboratories, Sumitomo Metal Industries, Ltd., Amagasaki)

The creep rupture strength of low alloy steels, $1 / 2 \mathrm{Mo}, 1 \mathrm{Gr}-1 / 2 \mathrm{Mo}, 21 / 4 \mathrm{Cr}-1 \mathrm{Mo}, \quad 5 \mathrm{Cr}-1 / 2$ Mo, $9 \mathrm{Cr}-1 \mathrm{Mo}$ was studied in relation to their microstructure.

The results obtained are as follows ;

(1) The intersection of the stress-rupture time curves was observed in a steel with different heat treatment. This was observed also in $1 \mathrm{Cr}-1 / 2 \mathrm{Mo}$ and $21 / 4 \mathrm{Cr}-1 \mathrm{Mo}$ steels.

(2) High Cr steels ( $5 \mathrm{Cr}-1 / 2 \mathrm{Mo}, 9 \mathrm{Cr}-1 \mathrm{Mo}$ ) show weaker creep strength than low $\mathrm{Cr}$ steels (1/2 Mo, LCr-1/2 Mo, $21 / 4 \mathrm{Cr}-1 \mathrm{Mo})$.

(3) The $\mathrm{Cr}$ content in the residues does not increase by tempering. As for the amount of Mo in the residues, low $\mathrm{Cr}$ steels show remarkable increase in Mo content but high $\mathrm{Cr}$ steels show slight increase in Mo content.

(4) Microscopical observation revealed that N. T. treated specimen contained finer precipitates in the ferrite than Ann. treated specimen. Tempered bainite which was observed in N.T. treated $21 / 4 \mathrm{Cr}-1$ Mo steel was apt to form coarse carbides.

In fine the problems with the creep rupture strength of commercial low alloy steels will more clearly be boiled down to alternative between the following two questions :

(1) whether or not the low alloy steels contain in their microstructure either bainite or martensite, or (2) whether or not the ferrite is adulterated with carbide particles.

(Received Nov. 4, 1971)

\section{1 緒言}

Mo 鋼和よび Cr-Mo 鋼は高温用材料として広く用 いられて抢り焼もどしによる組織変化, クリープ破断 材の組織変化等についてもすでに報告がある。1゙．ただ実 用鋼では Cr と Moが共存するために観察される炭化 物の種類, 形態ともに変化富んでおりそのために焼 もどしによる炭化物の変態は複雑化している。

クリープ破断強度に及洔す前組蟣の影響については クリープ速度またはクリープ破断試験によって調べら れている。これらの報告によれぼ高応力短時間側では ベイナイト組織のものか高いクリープ破断強度を示し フェライト・パーライト組織のものが低いクリープ破 断強度を示している。ただこれらのクリープ応力一破 断時間曲線を比較すると知られるようにベイナイト組 織の応力一破断時間曲線はフェライト・パーライト組 織のものに比べてそのこう配は急になる傾向がある。 これに伴う組織的な面での差としては針状の炭化物の

* 原稿受理 昭和46年11月 4 日

** 住友金属工業(株)中央技術研究所 尼崎市西長洲本通
析出という点が指摘されているだけであり詳細な比較 検討はなさ秘ていない。

炭化物の変態飞及涪す $\mathrm{Cr} ， \mathrm{Mo}$ 量の影響については 種々の報告があり年尔らの炭化物变態の系統化につい ても試みられている。一方クリープ破断強度について は個々にある同一鋼内ての組織面での検討はなされて いるが，同一鋼内または鋼種閒のクリープ強度と絽織 の相互比較は未だ試みられていないよろである。

最近当社に特いて炭素鋼，フェライト系低合金鋼， オーステナイト系ステンレス鋼について多数の長時間 クリープラプチャーデータが得られた。 その中から同 一材で前組織の差によりクリープ応力一破断時間曲線 の交さするるのを含めて $1 / 2 \mathrm{Mo}, 1 \mathrm{Cr}-1 / 2 \mathrm{Mo}, 21 / 4 \mathrm{Cr}$ $-1 \mathrm{Mo}, 5 \mathrm{Cr}-1 / 2 \mathrm{Mo}, 9 \mathrm{Cr}-1 \mathrm{Mo}$ の各鋼について同一 材での前組織の影響拉よび鋼種間の比較を炭化物の分 布状況を中心行ない, クリープラプチャ一強度と組 織の関連をより統一的には握することを試みた。

\section{2 実 験 方 法}

供試材の化学成分, 熱処理および熱処理のままの組 
Table I. Steels tested

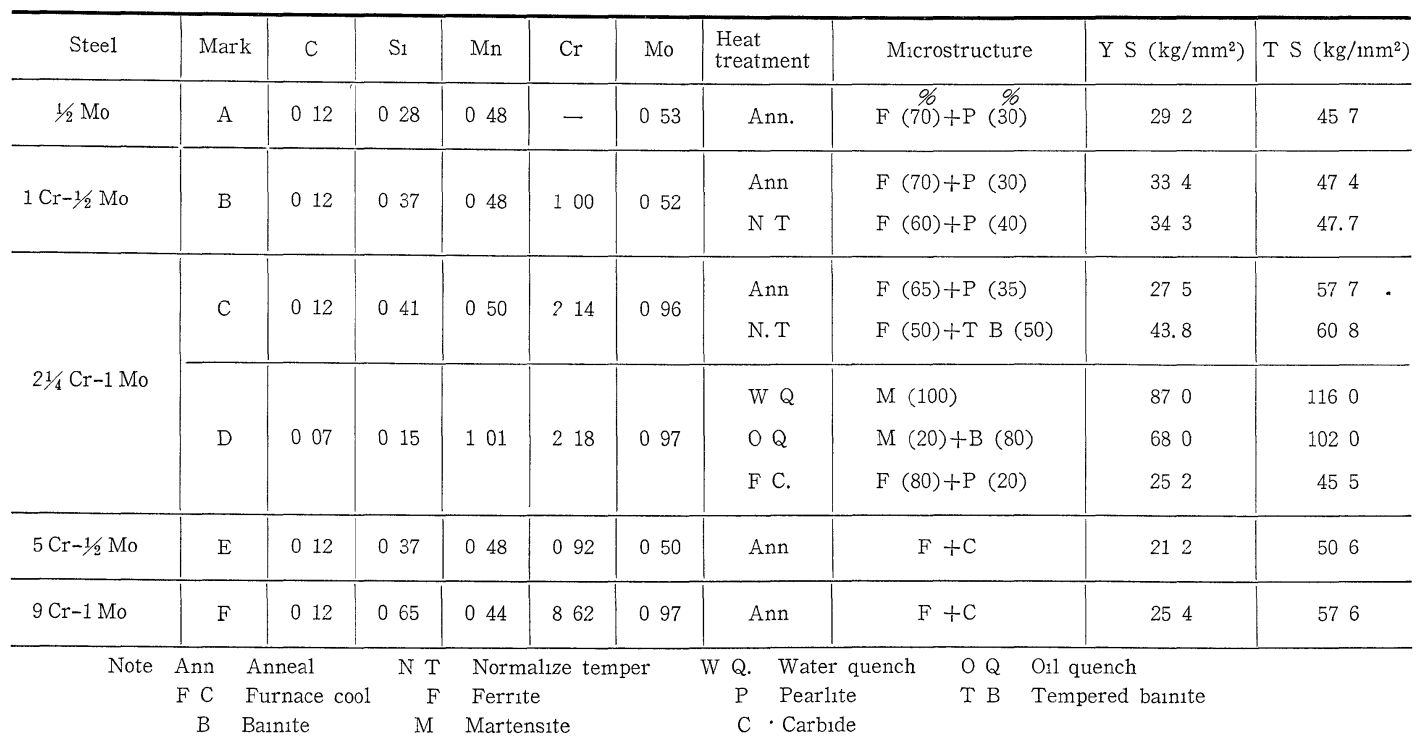

織を Table I に示す。 D鋼以外はいずれも害用鋼で あり $0.5 \% \mathrm{Mo}$ ベースの $0,1 ， 5 \% \mathrm{Cr}$ 鋼，1\% Moベ ースの $21 / 4 \mathrm{Cr}, 9 \mathrm{Cr}$ 鋼の計 6 鋼種である. 熱処理ま まの組織を比較すると A， B ，C鋼はいずれもフェラ イトとパーライトまたはべイナイトの 2 相組織になっ ているが $\mathrm{E}, \mathrm{F}$ 鋼てはフェライトとパーライト部分の 区別はほとんど認められない。また同一材て熱処理の 異なるものについて比較してみるとAnn.(焼なまし) 材にくらべてN.T.材(班隼焼もどし)のほうがフェラ イト量が少なくなる傾向にある、特にC 鋼では Ann. 材がフェライト・パーライト組織であるのに対して N. T. 材がフェライト・ベイナイト組織である点か異 なっている，D鋼は均一マルテンサイト，ベイナイト とフェライト・パーライト組織のリリープ破断性質を 明らかにするだめに用いた。水冷材はマルテンサイト， 油冷材はほとんどベイナイト，炉冷材はフェライト・ ハーーライトからなっている。

500〜 650 C で長時間クリープラプチャ一試験を行な った・クリープ破断試駼片々用いて電子顕微鏡による 組織観察, 電解抽出残渣中の $\mathrm{Cr}, \mathrm{Mo} の$ 定量等を行な った。

\section{3 試 験 結 果 \\ $3 \cdot 1$ クリープ破断試験結果}

$3 \cdot 1 \cdot 1$ 同一材における前組織の影響 供試枌の 応力一破断時間曲線を Fig. 1 (a), (b), (c) に示す. B， $\mathrm{C}, \mathrm{D}$ 鋼いずれも高応力短時間側と低応力長時間側で は前組織のクリープ破断時間に及ぼす影響が逆転して いる. B 鋼では高応力長時間側では Ann. 材が，低応 力長時間側ではN.T.材が長い破断時間を示すのに対 して C 鋼では高応力短時間側で N.T. 材が，低応力長

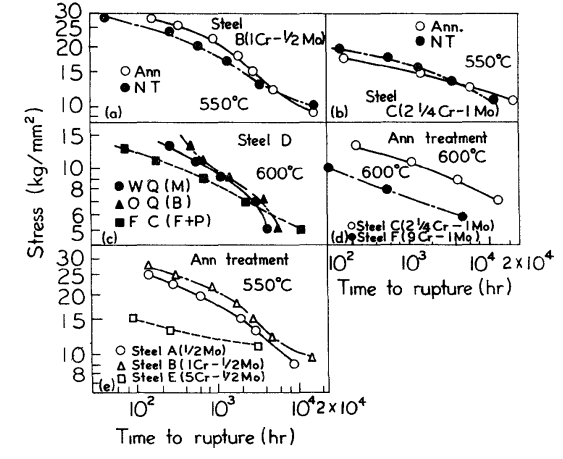

Fig. 1. Relationship between stress and time to rupture for steels studied.

時間側では Ann. 材が長い破断時間を示している。一 方 D鋼では高応力短時間側で O.Q. 材が，低応力長時 間側では F.C. 材が一番長い破断時間を示している.

$3 \cdot 1 \cdot 2$ 鋼種間の比較 応力一破断時間曲線を Fig. 1 (d)(e)飞示す. 1/2Moヘース鋼では，クリープ破断却 度は $\mathrm{B} \rightarrow \mathrm{A} \rightarrow \mathrm{E}$ 鋼の順に低下し, $\mathrm{Cr}$ 含有量の商い $\mathrm{E}$ 鋼のクリープ破断強度は特に低い. $1 \mathrm{Mo}$ ヘミース鋼に 执いても高い Crを含有する $\mathrm{F}$ 鋼は低いクリープ破断 強度を示している。

\section{$3 \cdot 2$ クリープ破断試験片の組織変化}

$3 \cdot 2 \cdot 1$ 同一材における前組織の影響 フェライ ト中の炭化物の析出状況を Ann. 材と N.T.材を比較 して, Fig. 2(1 Cr-1/2 Mo), Fig. 3(21/4 Cr-1 Mo) に 示す. $1 \mathrm{Cr}-1 / 2 \mathrm{Mo}$ 鋼执よび $2 \frac{1}{4} \mathrm{Cr}-1 \mathrm{Mo}$ 鋼の両鋼と b N.T.材の添らが Ann. 材にくらべて析出が遅れる 傾向が誑められる。すなわら熱処理ますでは.Ann. 材 のほうが N.T.材にくらべて析出物数が多い.しかし 


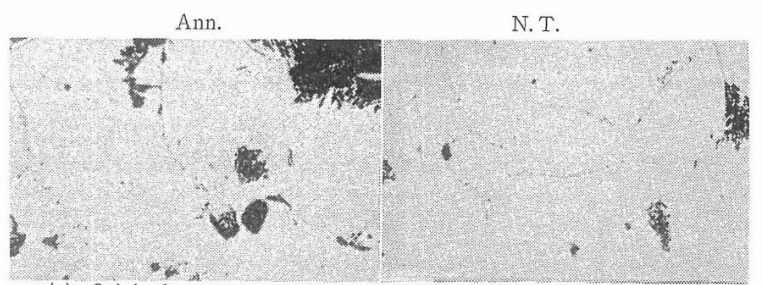

(a) Original structure

(d) Original structure

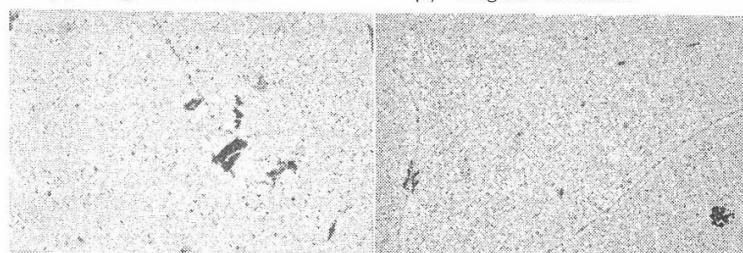

(b) $550^{\circ} \mathrm{C} \times 2829 \mathrm{hr}(19.3)$

(e) $556^{\circ} \mathrm{C} \times 3493 \mathrm{hr}(19.37)$

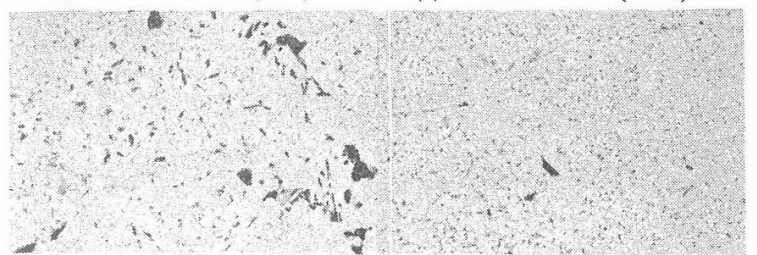

(c) $550^{\circ} \mathrm{C} \times 17446.5 \mathrm{hr}(19.95)$

(f) $550^{\circ} \mathrm{C} \times 15814.2 \mathrm{hr}(19.91)$

$10 \mu$

Fig. 2. Electron microstructure of steel B.
Ann.

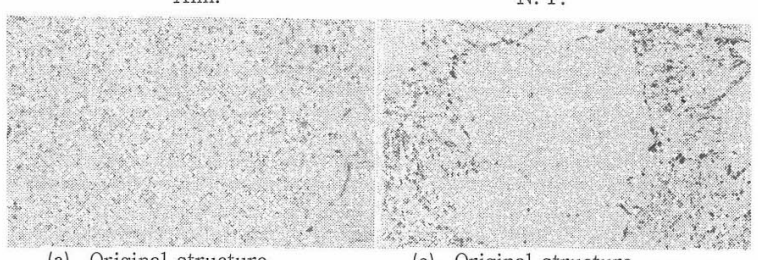

(a) Original structure

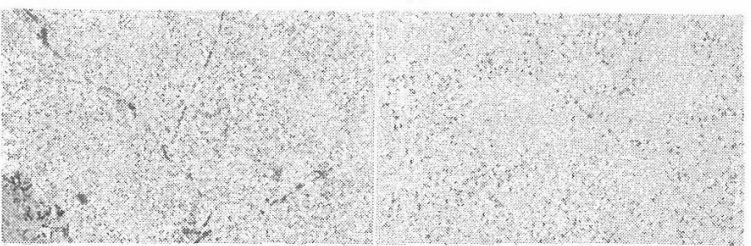

(b) $500^{\circ} \mathrm{C} \times 7845.8 \mathrm{hr}(18.47)$

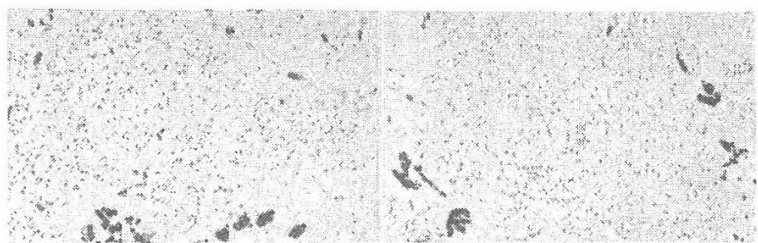

(c) $650^{\circ} \mathrm{C} \times 4.12 \mathrm{hr}(20.87)$

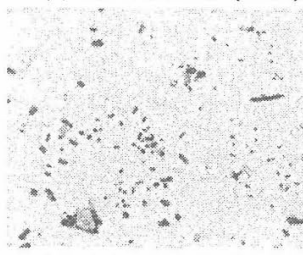

(d) $650^{\circ} \mathrm{C} \times 3689.5 \mathrm{hr}(21.75)$ (g) $600^{\circ} \mathrm{C} \times 2281.5 \mathrm{hr}(20.39)$

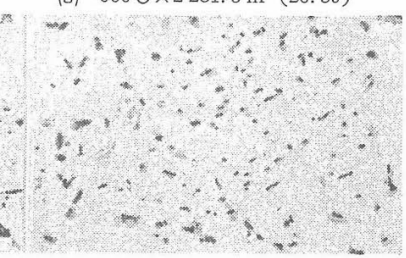

(h) $650^{\circ} \mathrm{C} \times 5004 \mathrm{hr}(21.84)$
$10 \mu$

Fig. 3. Electron microstructure of steel C.
クリープ菇もどしによってN.T. 材にも多数の析 出物が認められるようになりさらに气の析出物が 成長する。したがってフェライト粒内の炭化物の 成長挙動々関する限りこのB 鋼 $(1 \mathrm{Cr}-1 / 2 \mathrm{Mo})$ と C 鋼 $(21 / 4 \mathrm{Cr}-1 \mathrm{Mo})$ の間に棌之んど差はない。

一方パーライト部分についてみると Fig. 4 に示 す上 5 飞B鋼の Ann. 材と N. T. 材の球状化挙動 は大差ないのに詨してC鋼の Ann. 材と N. T. 材 の球状化挙動には明確な差が認めら礼る。すなお ら Table I にも示したようにB鋼では両处理と もブェライトと層状のパーライトより成るのに対 してC 鋼では Ann. 材はフェライトと層状パーラ

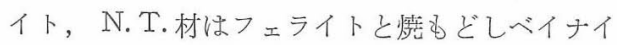
トよりなっている。このC鋼に扮いて両処理によ って生じた組織上の差すなわち層状パーライトで

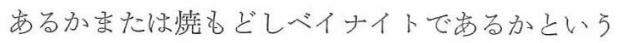
ことがクリープ煰もどしに際しての球状化の難易 となって㐫られれたものと考党られる。焼もどし ベイナイトは転位密度が高いためにこの様な粗大

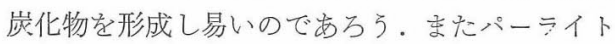
部分について B 鋼と C 鋼を比較すると明らかに異 なった形の羽毛状の炭化物 $\left(\mathrm{M}_{2} \mathrm{C}\right.$ と同定される。) がC鋼に認められこれは $\mathrm{M}_{7} \mathrm{C}_{3}$ または $\mathrm{M}_{23} \mathrm{C}_{6}$ 型 のパーライトにくらべて若丁安定でむり球状化の 幄れる傾向が办られる。

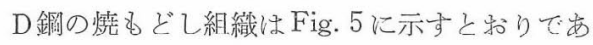
る. 水冷材では lath 状マルテンサイト, 油冷枌で

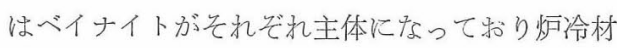
はフェライトとパーライトがらなっている。水冷 材では焼るどしによって多数の粒状炭化物 $\left(\mathrm{M}_{3} \mathrm{C}\right.$ または $\mathrm{M}_{7} \mathrm{C}_{3}$ と同定される。）在生成し鉝状の炭 化物 $\left(\mathrm{M}_{2} \mathrm{C}\right.$ と同定される。) る認められる。長時 間の焼もどしによって塊状の炭化物がみられるよ らになる。油冷材では焼もどしによって主に針状 の炭化物が析出し粒状のもの若干みとめられる。 さらに長時間莯もどしによって塊状炭化物が生成 するのは水冷材と同㥞である。炬冷村のパーライ 卜部分は先述のC 鋼に類似している。フェライト 部分にも炣冷まをで若干の針状炭化物が析出して いるが焼もどしによってパーライト部近傍，精界 近傍から徐ふにつェライト結晶粒内に析出が進行 する．Fig. 5 の(g)(h)(i)を比校すると知られるよ に水冷または油冷材の上らに急冷したものでは針 状炭化物は洼と几ど消隇しているが，炬冷村の針 状炭化物は焼るどしに対してかなり安定である。 すな子方炻冷材の釗状炭化物はクリープ中に徐々 に析出ないし成長することが知られこれが低応力 長時間側のクリープ強度に寄与していると考光ら 


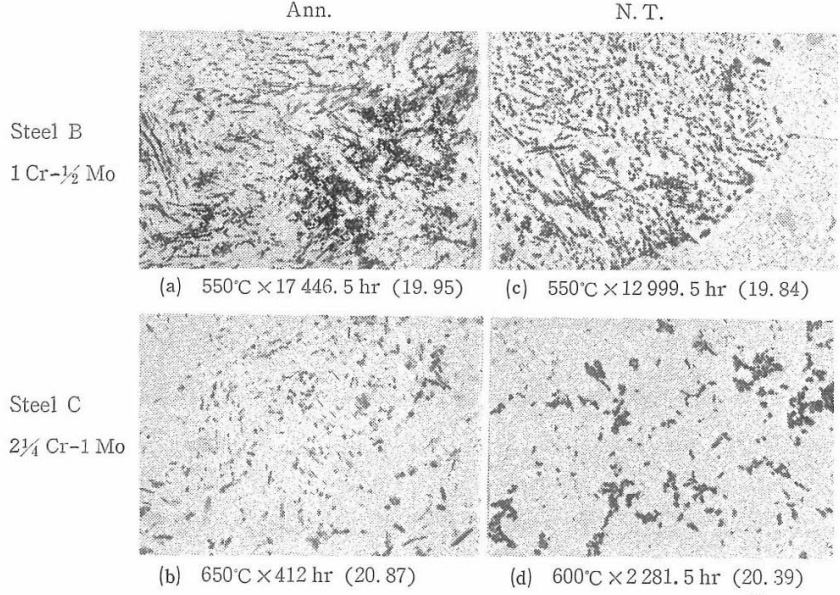

(b) $650^{\circ} \mathrm{C} \times 412 \mathrm{hr}(20.87)$

Fig. 4. Electron microstructure of pearlitic region.

れる。

$3 \cdot 2 \cdot 2$ 鋼種間の比較 Fig. 6 に 1/2 Moベース鋼 の組蟣変化を比較して示す．ここでは便宜的に L. M. 值を 1 つ目安として鋼種間の此較を行なうことにし た. $\mathrm{A}$ 鋼 $(1 / 2 \mathrm{Mo})$ はフェライト・パーライト組織 示しており焼もどしによってフェライト中には針状炭 化物の析出および成長がみら机る。E鋼( $5 \mathrm{Cr}-1 / 2 \mathrm{Mo})$ では層状組織を是する部分も一部みとめられるが大部 分はフェライト中に分散した種々の形状の炭化物から なりたっている。したがって

$10 "$

化物の変化は主に凝集粗大化でありフェラ イト部分に批る新たな析出はまったく認 められない， B 鋼 (1 Cr-1/2 Mo) について はすずに述べたよらにフェライト中に多数 の析出物が認められる。これらの組織を比 較すると明らかなようにA，B鋼はフェラ イト中に微細分散した炭化物が存在するの に㸚して $\mathrm{E}$ 鋼では比較的粗大な炭化物がつ ェライト中に分散して括りその粗大化凝集 が変化の中心である。

以上に述べた $\mathrm{A} ・ \mathrm{~B}$ 鋼と $\mathrm{E}$ 鋼のちがいは $\mathrm{C}$ 鋼と F 鋼を比较した場合にも認められる。 Fig. 7 に示玄よ5にF鋼 $(9 \mathrm{Cr}-1 \mathrm{Mo})$ は $\mathrm{E}$ 鋼 (5 Cr-1/2 Mo) の組織之類似し粗大な 炭化物がフェライト中に分散している。新 たなフェライト中での析出は認められずE鋼 之同様に宸化物の凝集粗大化が変化の中心である.

\section{4 考察}

\section{$4 \cdot 1$ 炭化物変態について}

すでに述へたように炭化物形態かっるみと高 $\mathrm{Cr}$ 鋼 ( $\mathrm{E}, \mathrm{F}$ 鋼) と低 $\mathrm{Cr}$ 鎆 ( A , B , C , D 鋼) の閒に はっきりとした差が認められる。すなわち高 Cr 鋼の 炭化物は比輘的粗大でありかつ分散して未り低 Cr 鋼 の場合のパーライト領域に相当するるのを識別するこ とは困難である。低 Cr 鋼に抏いてフェライト中に析 出才る釗状の $\mathrm{M}_{2} \mathrm{C}$ 型の炭化物は高 $\mathrm{Cr}$ 鋼ではほとえ

W. Q.

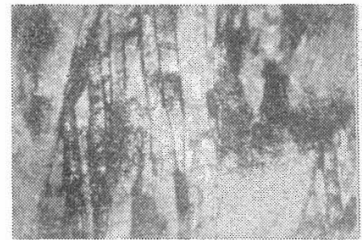

(a) Original structure

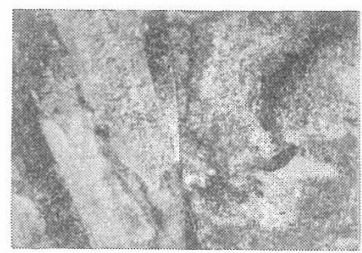

(b) Original structure

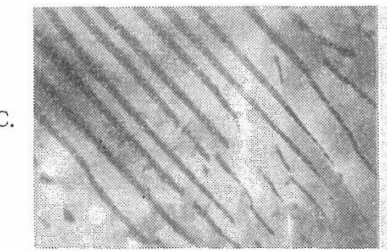

(c) Original structure

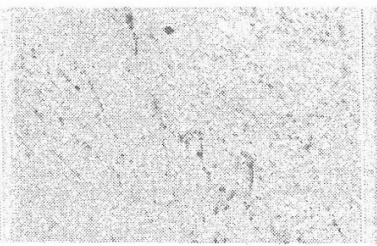

(d) $600^{\circ} \mathrm{C} \times 250 \mathrm{hr}(19.55)$

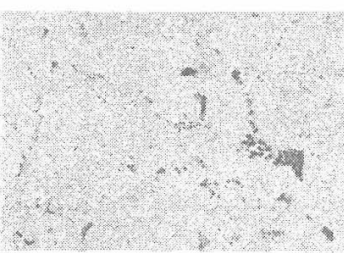

(e) $600^{\circ} \mathrm{C} \times 4848 \mathrm{hr}(19.80)$

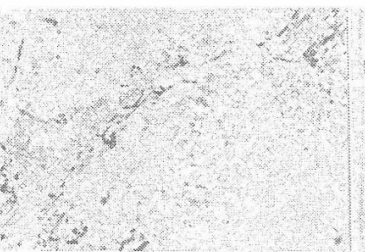

(f) $600^{\circ} \mathrm{C} \times 62.9 \mathrm{hr}(19.03)$

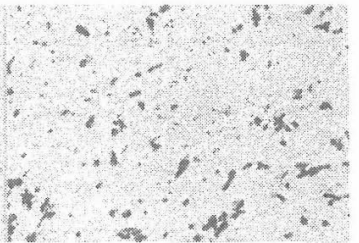

(g) $600^{\circ} \mathrm{C} \times 3987 \mathrm{hr}(20.60)$

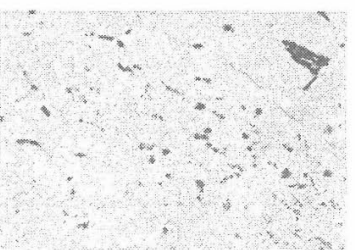

(h) $600^{\circ} \mathrm{C} \times 5904.3 \mathrm{hr}(20.75)$

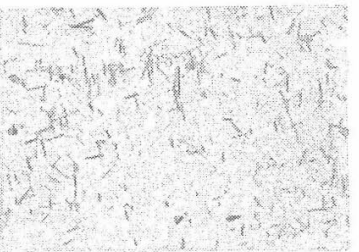

(i) $600^{\circ} \mathrm{C} \times 10395.4 \mathrm{hr}(20.97)$

$10 \mu$

Fig. 5. Electron microstructure of steel D. 


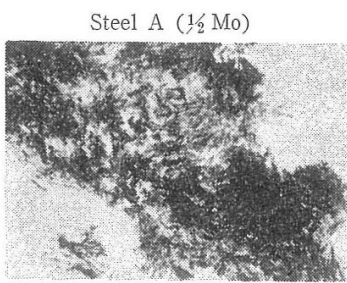

(a) Original structure

(b) $550^{\circ} \mathrm{C} \times 8646 \mathrm{hr}(19.7)$ Heat treatment : Ann.

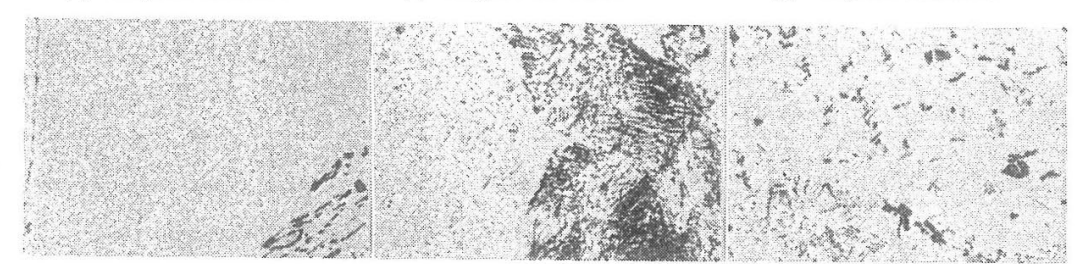

Steel B ( $1 \mathrm{Cr}-1 / 2 \mathrm{Mo})$

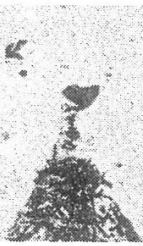

(c) Original structure
Steel E (5 $\mathrm{Cr}-1 / 2 \mathrm{Mo})$

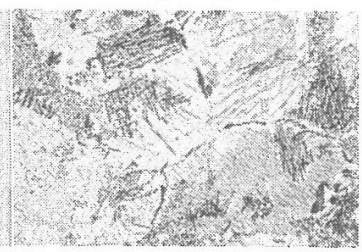

(f) Original structure

(d) $550^{\circ} \mathrm{C} \times 4949 \mathrm{hr}(19.5)$

(g) $600^{\circ} \mathrm{C} \times 118 \mathrm{hr}(19.3)$

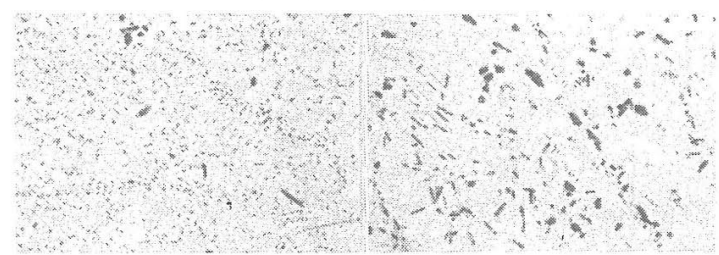

(e) $600^{\circ} \mathrm{C} \times 5458 \mathrm{hr}(20.7)$

(h) $600^{\circ} \mathrm{C} \times 8633 \mathrm{hr}(20.9)$

$10 \mu$

Fig. 6. The comparison of electron microstructures ( $1 / 2$ Mo base steels).

Steel C $(21 / 4 \mathrm{Cr}-1 \mathrm{Mo})$

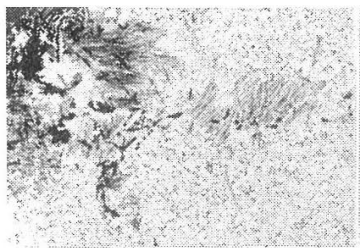

(a) Original structure

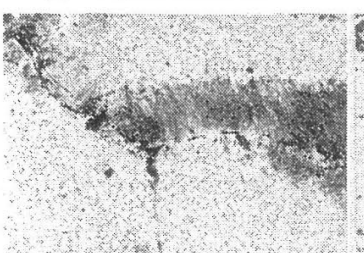

(b) $550^{\circ} \mathrm{C} \times 7846 \mathrm{hr}(18.5)$

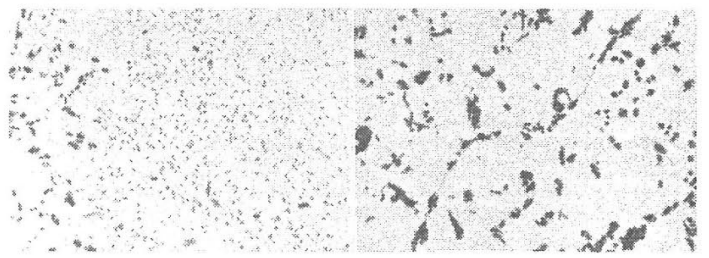

(c) $650^{\circ} \mathrm{C} \times 412 \mathrm{hr}(20.9)$

(f) $600^{\circ} \mathrm{C} \times 5146 \mathrm{hr}(20.7)$

$10 \mu$

Fig. 7. The comparison of electron microstructures (1 Mo base steels).

ぞ認められず逆に低 $\mathrm{Cr}$ 鋼では源とえど認められなか った $\mathrm{M}_{6} \mathrm{C}$ 型の炭化物が高 $\mathrm{Cr}$ 鋼ではしばしば認めら

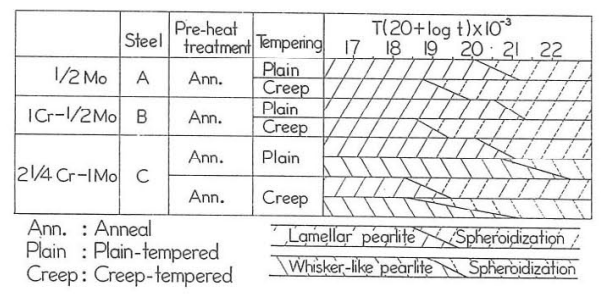

Fig. 8. The spheroidization of lamellar and whisker-like carbides.

れる。したがって高 $\mathrm{Cr}$ 鋼では $\mathrm{M}_{7} \mathrm{C}_{3}, \mathrm{M}_{23} \mathrm{C}_{6}, \mathrm{M}_{6} \mathrm{C}$ 等の宸化物が主体で㘯るのに対して低 $\mathrm{Cr}$ 鋼ではフェ ライト中では $\mathrm{M}_{2} \mathrm{C}$ が, パーライト中では $\mathrm{M}_{23} \mathrm{C}_{6}$, $\mathrm{M}_{7} \mathrm{C}_{3}$, ベイナイト中では $\mathrm{M}_{2} \mathrm{C}, \mathrm{M}_{7} \mathrm{C}_{3}$ がそれぞれ主 体である。

またAnn.材のパーライト部分にみられる層状炭化 物についてみると A， B 鋼とC 鋼の間に明確な差の認 あられる宸化物がある。乞玌は $\mathrm{M}_{2} \mathrm{C}$ と同定される将 毛状の炭化物でありこの炭化物は $\mathrm{M}_{23} \mathrm{C}_{6}$ または $\mathrm{M}_{7} \mathrm{C}_{3}$ 型の層状炭化物に比べて球状化が遅机る傾问が認めら れる.Fig. 8 に球状化傾向の比較を示す。これらの層 状炭化物の球状化は炭素鋼に文られ爷 $\mathrm{Fe}_{3} \mathrm{C}$ の球状化 （L.M. 值 17.5〜18. 付近で生ずる.）に比べるといず 机当㜊机て的り球状化は $\mathrm{M}_{3} \mathrm{C} \rightarrow \mathrm{M}_{23} \mathrm{C}_{6}, \mathrm{M}_{7} \mathrm{C}_{3} \rightarrow \mathrm{M}_{2} \mathrm{C}$ の順に難しくなっている。 Craft 特よび T. Mukherjee らによって示さ机ている 球状化が $\mathrm{M}_{3} \mathrm{C}$ よりる $\mathrm{M}_{7} \mathrm{C}_{3}, \mathrm{M}_{23} \mathrm{C}_{6}$ のほうが遅れる 
とする傾向と類似している。ただ $\mathrm{M}_{2} \mathrm{C}$ 型の羽毛状炭 化物がさらに安定であるといら点については炭化物そ のものの安定性の他他鉄との整合性と言了点も含め て検討の余地があうう。

\section{$4 \cdot 2$ クリープ強度と組織の関連性について}

Fig. 2〜7 亿示した組織变化から知られるよ5に少 なくとも低 $\mathrm{Cr}$ 鋼と高 $\mathrm{Cr}$ 鋼の間にみられるクリープ 破断強度の差は炭化物形態, 分布からみた差と上く対 応している。また応力一破断時間曲線の交差を示す同

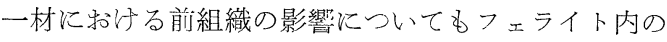
析出状沉またはハ・ーライト部分の球状化挙動を比較す るとクリープ破断強度との対応性が認められる。これ らの点に注目して一定面積内の析出物数を測定しこれ を析出物分布の目安として相対的な比較を行ならこと にした。焼入焼もどし鋼について行なわれているよ5 な平均粒䦌隔を求めるのが望ましいのであるが炭化物 形態が変化富んでいることを考慮して特に求めなか ったが，相対的には析出物数の多い場合は平均析出物 間隔が小さいことに対応する。

$4 \cdot 2 \cdot 1$ 同一材における前組織の影響 Fig. $9 ， 10$ 飞B 鋼 $(1 \mathrm{Cr}-1 / 2 \mathrm{Mo})$ と $\mathrm{C}$ 銅 $(21 / 4 \mathrm{Cr}-1 \mathrm{Mo})$ の Ann. 材と N. T. 材を比䡆して示す.

前述のように B 鋼, C 鋼ともに熱処理ままではフェ ライト中の析出物数は Ann. 材の潘らが N. T. 材より も多い。しかしクリープ焼もどしによって N.T.材の フェライト中にも微細な針状炭化物が析出し一時的に はAnn. 材より多い析出数を示す。しかしさら飞長時 間の焼もどしによって Ann. 材と N.T. 材のフェライ ト中の析出物数は余り差がなくなる。このような炭化 物数の変化とパラメータにより整理したクリープ破断 強度を比較すると，B 鋼では高応力短時間側で Ann.

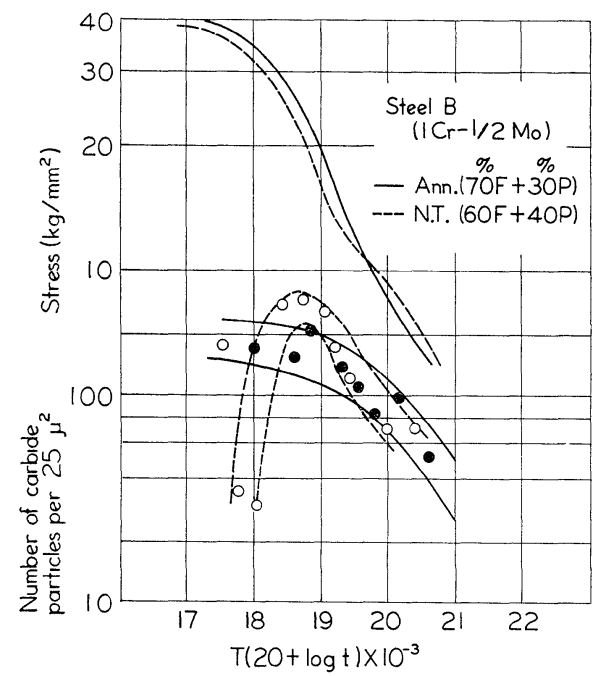

Fig. 9. Creep rupture strength and carbide distribution

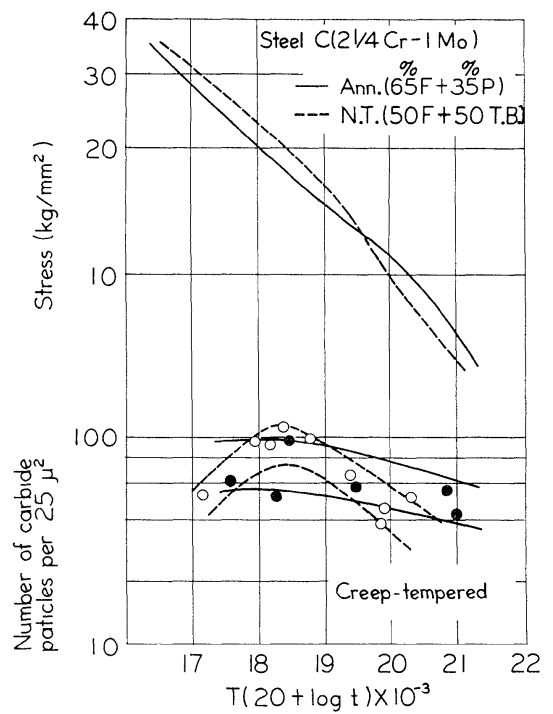

Fig. 10. Creep rupture strength and carbide distribution.

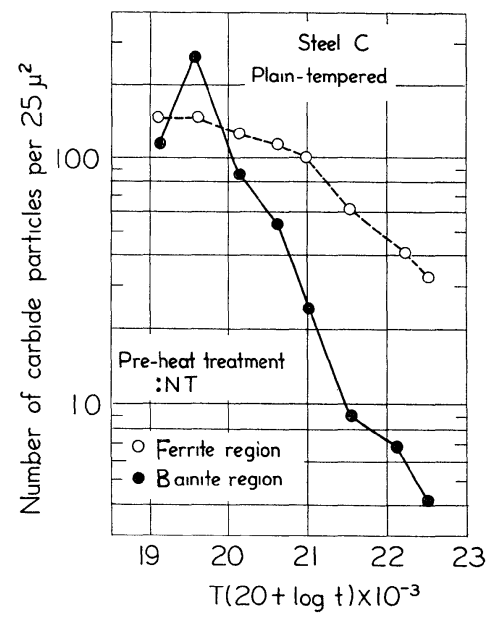

Fig. 11 Distribution of carbide particles in ferrite and bainite region

材が，低応力長時間側で N. T. 材が高いクリープ強 度を示寺傾向之析出物数の变化傾向々が良く一致して いる. しかし C 鋼ではフェライト中の析出物数とクリ 一プ強度の関係はB鋼と逆の傾向を示している。これ は Fig. 11 亿示すようにベイナイト部分の炭化物が粗 大化し易いことと関連がある。

$4 \cdot 2 \cdot 2$ 鋼種間の比較 $1 / 2 \mathrm{Mo}$ ベース鋼の比殡を Fig. 12 飞 1 Mo ベース鋼の比較を Fig. 13 飞示す. いずれの場合も特に $\mathrm{Cr}$ 含有量の高い $\mathrm{E}, \mathrm{F}$ 鋼ては筑 もどしによる析出物数の変化はゆるやかであるのに対 してフェライト粒内多数の針状炭化物を析出する $1 / 2$ Mo 鋼, $1 \mathrm{Cr}-1 / 2 \mathrm{Mo}$ 鋼怯相対的飞変化虻急である。 21/4 Cr-1 Mo 鋼は 1/2 Mo, 1 Cr-1/2 Mo 鋼にくらべて 高応力短時間側の析出物数は少なく低応力長時間側て 


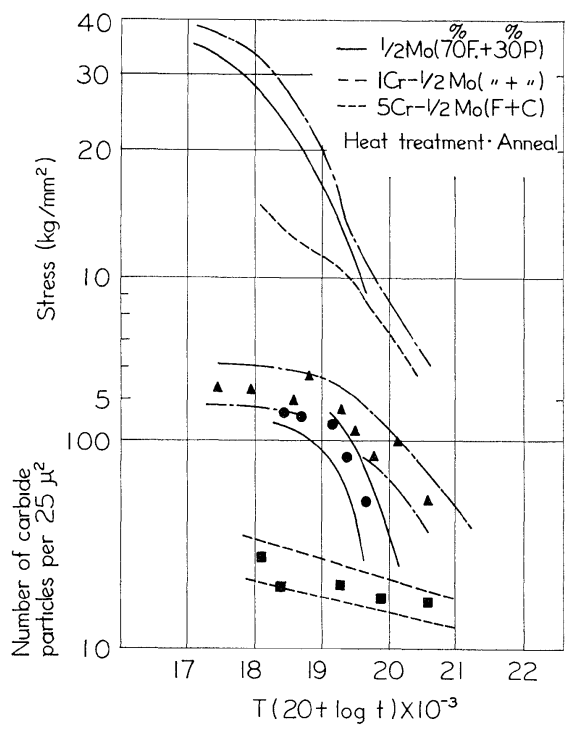

Fig. 12. Creep rupture strength and carbide distribution.

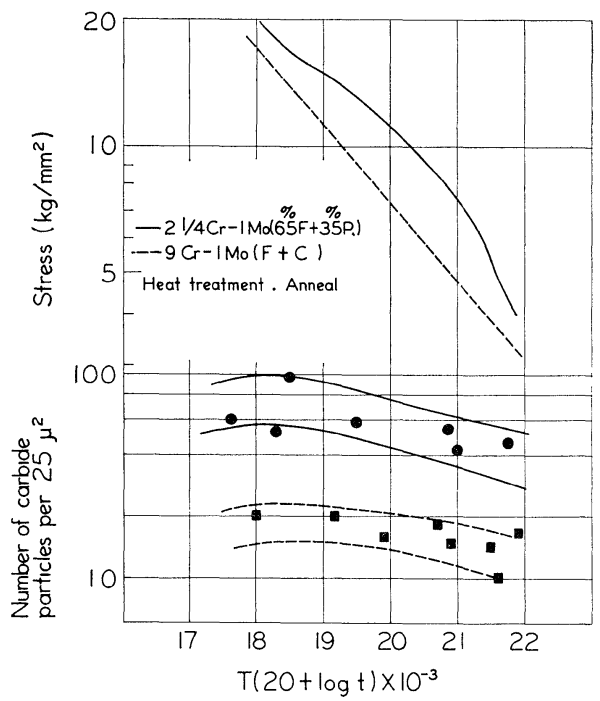

F1g. 13. Creep rupture strength and carbide distribution.

は多くなって㧍り焼もどし温度に対して析出物数の変 化が少なく安定であることを示している。

ここでは $1 / 2$ Mo ベース, 1 Moベースとして鋼種間 の比較を行なったが，これら全鋼種を比較してる相互 にかなりはっきりしたクリープ強度と析出物数の間の 関係が認められる。Flg. 12, 13 を比䡥すると $5 \mathrm{Cr}$ -

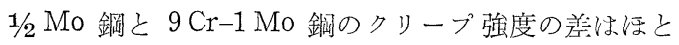
んぞなく析出物数についても同様である。またクリー ブ強度は $21 / 4 \mathrm{Cr}-1 \mathrm{Mo}$ 鋼が $1 / 2 \mathrm{Mo}$ 鋼忬よび $1 \mathrm{Cr}-1 / 2$ Mo 鋼に比へて高応力短時間側では低い強度を, 低応 力長時間側では高い強度を示しているが析出物数の変 化傾向之刘応している。
以上のように析出物数とクリープ強度の間にはかな りはっきりした相関が認められる。しかしクリープ強 度之析出物の間の定量的関係汇ついては析出時期の問 題と合わせた詳細な検討が必要である。

$4 \cdot 2 \cdot 3$ 残沮分析結果について Fig. 14 に電解法 による抽出残渣中の $\mathrm{Cr}$, Mo の定量結果を示す。炭 化物としての $\mathrm{Cr}$ 量怯全 $\mathrm{Cr}$ 含有量の10２0\%のとこ るに出り焼もとしにより若干增加する傾向に㐫るが Mo ほど顕著ではない，炭化物としての Mo 量の変化 はとの燒もどしによる增加僛向から高 $\mathrm{Cr}$ 材之低 $\mathrm{Cr}$

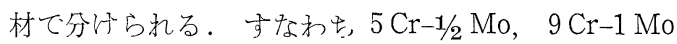
の各鋼ではその増加は僅かであり一方低 $\mathrm{Cr}$ 材では Mo の析出率は焼もどしによって〜70\%程度にも達する。 Crを含有しない単純な $1 / 2 \mathrm{Mo}$ 鋼では最初の析出は少 ないが焼もどしにより急激に析出し $21 / 4 \mathrm{Cr}-1 \mathrm{Mo}$, $1 \mathrm{Cr}-1 / 2 \mathrm{Mo}$ 鋼の昜合のゆるやかな析出傾向之対照的 である。このような残睢分析結果は組織篗察の結果と 上く対応することから $\mathrm{M}_{23} \mathrm{C}_{6}, \mathrm{M}_{6} \mathrm{C}$ 中への $\mathrm{Mo}$ の濃 縮よりもフェライト中への $\mathrm{M}_{2} \mathrm{C}$ の析出と刘応してい ると考究られる。

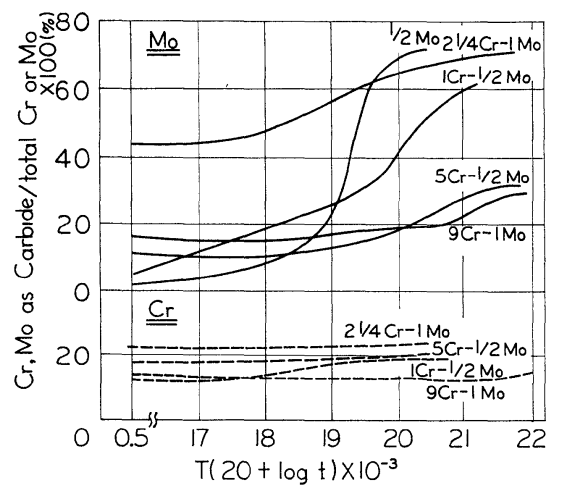

Fig. 14. The effect of tempering on the amount of $\mathrm{Cr}$ or Mo as carbides in steels studied.

\section{$4 \cdot 2 \cdot 4$ クリープ強度と析出物の関連について}

年用低合金鋼のクリープ破断强度に対して析出物がと の程度の役割りを果しているかという点を定量的に表 わすことは難かしい。たと常が常强度については析 出物が微細で地鉄之整合性を保っている状態がもっと る效果的であるとされているが，F1g. 9 でも知られる ように高温强度に対してはクリープ中での炭化物の成 長の問題もあり必ずしも整合性のある状態が效果的と はいい難い. B 鋼 ( $1 \mathrm{Cr}-1 / 2 \mathrm{Mo})$ の場合高応力短時間 側では Ann. 材が強く低応力長時間側では N.T. 材が 強くなっている.すなわち最初析出物の多いAnn. 材 が短時間側で強く, 多数の析出が生じた後ては N.T. 材が強くなっている。このことは析出物としてある程 度大さくなったものが高温強度に效いていることを示 
唆している。ただクリープ破断強度に対しては析出物 の析出時期がとりわけ長時間の場合意味を持っている と考えられ，このことが最大析出数を示す時期とクリ ープ強度の逆転の時期が一致しない原因と考光る。D 鋼において F.C. 材が低応力長間時側で 良好なクリー ブ強度を示すのもこのクリープ中に括ける析出の重要 性を示唆している.

以上に述べたように害用の低合金鋼に括いては析出 物がかなり重要な役割りを果している。クリープ強度 と析出物数之の定量的な関係については前述のように 析出時期の問題もあり，また鋼種間の比較に沶いては クリープ破断の現象的な差についてる注意する必要が める.この点については 1 つはたと它ば $1 / 2$ Mo 鋼に みられるよらなフェライト粒形のほとんど変形しない クリープ破断が嵓りクリープ中に拈ける加工硬化と回 復に対する析出物の役割りの解明が必要であると考光 る. また従来提案されている固溶強化, 析出強化, そ の汪かドラッギングによる強化等に対しても応力, 温 度等との関連に就いての効果の比較が必要であるう。

いずれにしても実用鋼ではフェライト中に特ける析 出物が強化作用の大きな部分を占めていると考えられ， またその析出時期についても考慮する必要のあること が推定される。

\section{5 総括}

$1 / 2 \mathrm{Mo}, 1 \mathrm{Cr}-1 / 2 \mathrm{Mo}, 21 / 4 \mathrm{Cr}-1 \mathrm{Mo}, \quad 5 \mathrm{Cr}-1 / 2 \mathrm{Mo}$, $9 \mathrm{Cr}-1$ Mo 鋼についてクリープ破断材の組織を調べた 結果を要約すると次のと和りである。

(1) 前組織の差によってクリープ破断強度の逆転が 認められたのは $1 \mathrm{Cr}-1 / 2 \mathrm{Mo}, 21 / 4 \mathrm{Cr}-1 \mathrm{Mo}$ の各鋼で める・

(2) Cr 含有量の高い $5 \mathrm{Cr}-1 / 2 \mathrm{Mo}, 9 \mathrm{Cr}-1 \mathrm{Mo}$ 鋼は Cr 含有量の低い $1 / 2 \mathrm{Mo}, 1 \mathrm{Cr}-1 / 2 \mathrm{Mo}, 21 / 4 \mathrm{Cr}-1 \mathrm{Mo}$ 鋼に比べて低いクリープ強度を示す.

(3) 抽出残渣分析の結果，いずれの鋼種に扔いても $\mathrm{Cr}$ 量の焼もどしによる変化はわずかであるのに対し てMo 量の焼もどしによる増加は鋼種により差が認め られる。高 $\mathrm{Cr}$ 材 (5 Cr-1/2 Mo, $9 \mathrm{Cr}-1 \mathrm{Mo})$ では Mo の増加は少ないが低 $\mathrm{Cr}$ 材 (1/2 Mo, $1 \mathrm{Cr}-1 / 2 \mathrm{Mo}, 2 \frac{1}{4}$ Cr-1 Mo）では顕著な堌加が認められる。

(4) 組織よりみるとフェライト中の N. T. 材の析出 物はAnn. 材に比べて微細である. パーライト部分に ついてみると $2 \frac{1}{4} \mathrm{Cr}-1 \mathrm{Mo}$ 鋼の N.T. 材にみられる ベイナイトは焼もどしによって粗大炭化物を生成し易 い.また高 $\mathrm{C}_{\gamma}$ 材のフェライト中には微細な炭化物の 析出は認められない。

以上の事実から実用材のクリープ破断強度は析出物 の分布状態とかなり密接に関係している。李たクリー プ破断強度はフェライト中の析出物の大小，パーラィ
ト部分にベイナイトまたはマルテンサイトを含有して いるかどうかという点によって大略説明しうる。ただ 析出物の分布状沉のみでは充分に説明しきれない面も ありクリープ破断機構执よび析出物の役割りについて のさらに詳細な検討を要する。

（昭和46年 8 月21日 材鉬際会議金属材籵の高温強度に関するエクス テンションセミナにて講演）

\section{参考 文 献}

1) R.dal, K. A, and A. G. Quarrel1, JISI, 195, p. 307 (1960).

2) Ridal, K. A., and A. G. Quarrell, JISI, 200, p. 366 (1962).

3) Jenkıns, C. H. M, and E. A. Jenkınson, JISI, 185, p. 23 (1957).

4) Irvine, K. J., and J. D. Murray, I. S. I. Special Rep., No. 70, p. 246 (1961).

5）寺井庄治, 阿部 隆, 材料試験， 9, 137 (1960).

6) 三好栄次, 岡田隆保, 住友金属, 18, p. 393 (1966).

7) 三好栄次，岡田隆保，材料，13，144 (1964).

8) 耳野 亨, 木下和久, 井原義人, 学振耐熱材料委員会研 究報告, 9, No. 2 (1968).

9) Krisch, A., and F.K. Naumann, Archiv. Eisen, 41, p. 835 (1970).

10) Murphy, M.C., and G.D. Branch, JISI, 211, p. 546 (1971).

11) Hale, F., Metal Treatment and Drop Forging, 26, p. 145 (1959).

12) Olsen, G., Joint International Conference on Creep (1963).

13) Heger J. J., J. M. Hodge, and P. W. Marshall, Proceeding ASTM, 54, p. 105 (1954).

14) Dulıs, E. J., and G. V. Smith, Trans. ASM, 45, p. 627 (1953).

15）高尾善一郎, 西原 守, 平野 坦, 山本俊二, 材料試験, 9, 129 (1960)

16) Hopkin, L. M.T., and E.A. Jenkinson, JISI. Nov., p. 929 (1964).

17) Baker, R. G, and J. Nutting, JISI, 192, p. 257 (1959).

18) Andrews, K.W., and H. Hughes, JISI. Nov. p. 304 (1959).

19) Dyson, D. J., and K.W. Andrews, JISI. Feb. p. 208 (1969).

20) Kuo, K, JISI. Apr. p. 363 (1953).

21) Crafts, W., and J. L. Lamont, Met. Trans. 185, p. 957 (1949).

22) Niekerk, M. N., and B. B. Argent, JISI. Ang, p. 781 (1970).

23) Murphy, S, and A. Whiteman, Met. Sc1. Jour. 4, p. 58 (1970).

24) Goldschmidt, H J, JISI. Dec, p $345^{\circ}$ (1948).

25）鈴木 章，木下修司，井上 毅，神鋼技報， 21， 101 (1971).

26) Ronald, T.M. F., and C. Bodsworth, JISI. Mar., p. 252 (1965).

27) Beech, J, and D. H. Warrington, JISI. Mar, p. 460 (1966).

28) Hyam, E D, and J. Nuttıng, JISI. 184, p. 148 (1956).

29) Mukherjee, T., and W. F. Stumpf, et al, JISI. 211, p. 621 (1969).

30）須藤 一, 耐熱合金における基地の高温強度（講演テス ト) (1971). 